\title{
Service Sector as an Engine of Growth: Empirical Analysis of Rwanda
}

\author{
Jean Bosco Harelimana ${ }^{1} \&$ Beline Mukarwego ${ }^{1}$ \\ ${ }^{1}$ Kigali Independent University (Ulk), Rwanda P.O.BOX.2280, Rwanda \\ Correspondence: Jean Bosco Harelimana, Kigali Independent University (Ulk), Rwanda P.O.BOX.2280, Rwanda.
}

Received: March 22, 2021

Accepted: April 7, 2021

Online Published: April 30, 2021

doi:10.11114/bms.v7i2.5229

URL: https://doi.org/10.11114/bms.v7i2.5229

\begin{abstract}
This research was econometrically analyzing Service sector as an engine of growth: empirical analysis of Rwanda from 1995 to 2020. The data were collected from BNR and were analyzed using Eviews7. The study used different opinions of economists concerning the Philips curve, by constructing short-term and long-term Philips curves in Rwanda by making some conclusions about the results at the end. We pay special attention in our research to the study of Phillips curve made by some economists of the last period the findings of this study indicate the following results: *, ** and *** indicates rejection of the null hypothesis of unit root at $10,5 \%$ and $1 \%$ significant level, respectively. The SERV, FDI, LR, GR series are not stationary at level, and then we should test the Stationarity at the first difference. $(*),(* *) \&(* * *)$ represent respectively $10 \%, 5 \%$ and $1 \%$ level of significance.

The results give an indication for the existence of long-run relationship between SERV and growth. The max and trace values statistic strongly reject the null hypothesis for "none "cointegration vector in favor of at least one cointegrating vectors at the 1 percent significance level. The cointegrating vector representing the long run relationship between service and growth. The above is endogenous because its probability of chi-square 0.000025 is less than $5 \%$ level of significance and it answers the second hypothesis of a Variable that can help national bank of Rwanda to control money supply in the short-run.

The $\mathrm{P}$ - value of chi-square which is $\mathbf{0 . 0 7 9 1}$ and this is greater than 0,05 level of significant therefore, there is no short run causality between variables running from SERV, FDI, LR and GR at $5 \%$ level of significant. The results revealed out from the above table; LSERV, LFDI, LLR and LGR does Granger Cause LSERV at 10\% level of significant due to their probability of 0.0284 which is less than 0.10 level of significance but LSERV does not Granger Cause LSERV, LFDI, LLR and LGR at $10 \%$ level of significant due to their probability of 0.1224 which is greater than 0.10 level of significance.
\end{abstract}

Keywords: Service Sector, Foreign Direct Investment, Economic Growth

\section{Introduction}

Since 1940s, the services sector has emerged as the largest segment in and driving force of the economy, contributing a growing share to gross domestic product (GDP), trade and employment. The observation that an increase in incomes goes together with an increasing share of services in economic activity dates back to at least the 1940s (Clark, 1967; Fuchs, 1980; Kuznets, 1957).

The service sector contributes to productivity and economy-wide growth, as it provides essential inputs to other products and services. Many services have emerged as promising tradable services for developing countries, particularly with the development of telecommunications and information and communications technology (ICT) services. In addition, efficient services are catalysts for the expansion of regional and global value chains, (UNECA, 2015).

The contribution of services to economies has increased over time. In 1980- 2015, the share of services in GDP increased in all income level groups, including from 61 to 76 per cent in developed economies and from 42 to 55 per cent in developing economies. Services are predominant in all developing regions, including in the least developed countries (LDCs). The increase in services output in this period largely corresponds to a decline in industrial output in developed economies and a decline in agricultural output in developing economies. This may be seen as reflecting the two distinct forms of structural transformation. In developed economies, the services sector has grown, and productive resources have moved out of the industrial sector. In developing countries, particularly LDCs, productive resources have mainly moved out of the agricultural sector, to services (UNECA, 2015). 
Stojkoski, Utkovski, Z. and Kocarev, L. (2016) show that countries that present higher services export have also higher a economic complexity index (ECI). In the European region, Maroto-Sanchez and Cuadra-Ruara (2011) confirm that several service industries have shown dynamic productivity growth rates, contributing more than expected to productivity growth. This fact points that services require a larger amount of knowledge to be produced, comparing to other products. Besides, the results obtained show that economies whose export schedules is based on services have also more complex productive structures and higher long-term growth potential.

From 2015, UNECA has documented the performance of Rwanda in the service sector which shows that service exports grew from $\$ 59$ million in 2000 to $\$ 395$ million in 2011. A growth of more than 10 per cent occurred in wholesale and retail trade, education, finance and insurance, and transport, storage and communications since 2007. Over 2000 and 2011, the ICT sub-sector received investments amounting to $\$ 552$ million; exports of travel were equivalent to 63 per cent of total services' exports and 29 per cent of merchandise and services exports in 2011. By 2012, FDI stocks in services were the largest at $\$ 640.2$ million followed by $\$ 391$ million in ICT, $\$ 124.1$ million in finance and $\$ 125.1$ million in insurance, against just $\$ 90.8$ million in manufacturing. In the seven year government program, tourism is expected to grow at a compound annual rate of 25 per cent and by 2014 Rwanda had received 1,137,000 visitors mostly attracted by the Rwanda mountain gorilla, generating \$294 million (up from $\$ 62$ million in 2000). In addition, the government is committed to increasing investments in services up to $\$ 350$ million by 2016 from $\$ 46$ million in 2015 , (MINICOM, 2015).

Rwandan firms have an opportunity to serve this market, but will also face greater competition from businesses in countries with larger and more sophisticated industrial sectors, such as Egypt and Kenya. The report also said that Rwandan exports are underdeveloped vis-à-vis the rest of Africa. Although the export sector is growing, Rwanda lags other African nations in terms of exports as a percentage of GDP, (MINICOM, 2015).

It is reason why this study is going to be carried out in order to address the contribution of service sector towards economic growth has. Empirically, this study aims at analyzing the contribution of service sector on economic growth in Rwanda.

\section{Objectives}

The general objective of the study is to investigate the contribution of the determinants of service sector such as labour participation, GDP growth rate, foreign direct investment and services (GDP) on Rwandan's economic growth.

1. To assess the determinant of services in Rwanda.

2. To analyze the drivers of economic growth in Rwanda

3. To find out the incidence of services sector on economic growth of Rwanda.

\section{Literature}

The service sector worldwide played significant role in competitiveness agenda due to strong relationship with rest of economy, growth is closely connected with service which indirectly linked with human capital. Hoekman and Eschenbach (2005) found there was positive relationship between the service sector and economic growth, as economic growth rose with service sector growth. Arnold et al. (2008) suggested that finance, transport and telecommunication are the backbone of service sector which allowed business and open international market competition. Arnold et al. (2010) discovered India covering banking, insurance, telecommunication and transport improved their services polices which led to improve in manufacture productivity, this is the one another way that service sector has taken part in improving economic efficiency, therefore service sector plays important role in the growth of economy directly also indirectly. Miroudot et al. (2010) showed rapid productivity growth related with those service sectors which were more open to international competition.

Chang (2012) argues that a higher share of the services sector does not diminishes the importance of the industry. According to the author the industry is the source of knowledge to the services sector. The acquisition of knowledge in the services sector occurs through the search for real solution to problems faced by the industrial sector. Knowledge in itself is not enough to guarantee competitiveness in the intermediate services sector. In other words, it is the interaction between industry and services that results in a higher industrial density and economic complexity.

As emphasized earlier, the increase in the share of the services sector results in the increase in economic complexity. This concept is presented by Hidalgo and Hausmann (2009). According to these authors, the way which society found to make sophisticated products is by breaking down into "pieces" the required knowledge for manufacturing them. These pieces of knowledge are acquired and shared among the workforce. Each worker learns and specializes in one part of the necessary knowledge, which is subsequently offered in the job market. 
According to Hidalgo and Simões (2011), the productive capacity of each society can be measured by its capacity to retain, create, modify, organize, distribute and make use of the capabilities of its workforce. The most developed societies are the ones capable of managing more efficiently. The empirical evidences indicate that countries with higher economic complexity are developed countries. Their services sector also presents a higher share in added value. Therefore, the following question is raised, what is the relationship between the degree of development of the services sector and the level of complexity of the productive structure of a country? As showed by the services literature, this sector supplies the industrial sector with the required knowledge. The rise in the amount of productive knowledge used by a country leads to the emergence of various services activities that exercise different functions and supply the industry with the necessary knowledge.

Stojkoski, Utkovski, Z. and Kocarev, L. (2016) show that countries that present higher services export have also higher a economic complexity index (ECI). This fact points that services require a larger amount of knowledge to be produced, comparing to other products. Besides, the results obtained show that economies whose export schedules is based on services have also more complex productive structures and higher long-term growth potential.

Finally,On the performance and sector growth empirical studies greatly extended toward Lewis (1954) and Hirschmann (1958) dual economy model; which explained the association of agriculture sector (traditional) and manufacturing sector (modern). Glasmeier and Marie (1993) found that the two against vision on service sector impact on economic growth, one is service sector helped in economic growth on the other side service sector is depended neither alternate the conventional commodities producing sectors like mining, agriculture and manufacturing. Although since 1950 empirical finding suggests that dominating sector in developed countries is service sector Warton (1974). Economic Council of Canada (1991) reported that supremacy of service sector accounts to two thirds of employment and output in developed countries, in addition the association of service sector and economic growth depends on the size of sector and its productivity in economic. Mansell (1985) suggested service sector was based on export oriented if compare to commodities producing sector and source to decline in growth of trading partner. The service sector played significant role in national competiveness agenda its due to strong relationship with rest of economy, growth is closely connected with service which indirectly linked with human capital. Hoekman and Eschenbach (2005)found there was positive relationship between the service sector and economic growth, as economic growth rose with service sector growth. Arnold et al. (2008) suggested that finance, transport and telecommunication are the backbone of service sector which allowed business and open international market competition. Arnold et al. (2010) discovered India covering banking, insurance, telecommunication and transport improved their services polices which lead to improve in manufacture productivity, this is the one another way that service sector has taken part in improving economic efficiency, therefore service sector play important role in the growth of economy directly also indirectly. Miroudot et al. (2010) showed rapid productivity growth related with those service sectors which were more open to international competition.

Mujahad and Alam (2014) claim that an increase in the share of services in Pakistan's GDPis linked to population size and both internal and external factors. They conceptualizedomestic factors as household and government consumption, gross fixed consumption, labour participation, growth rate and literacy, while external factors are conceived as external totaldebt, foreign direct investments and trade liberalization measured by imports plus exportsdivided by GDP. Their results show that total debt, population, investments and GDP growthhad a negative effect on services. In contrast trade liberalization, labor participation,aggregate consumption and government spending had a positive effect on services.

Sahu (2015) analyzed micro-data on service sector companies to test high growth in totalfactor productivity (TFP) assessing if better factor allocation led to TFP growth. He foundthat a reduction in the misallocation of resources in the service sector resulted in anaccelerated pace of TFP growth. Therefore, the communication and community serviceindustries registered the fastest growth in terms of moving towards efficient TFP levels. Acharya (2016) affirms what accounts for exceptional TFP growth performance in some.

ICT industries using industries where productivity gains in the production of ICT are given as an answer in the US and in the Organization of Economic Cooperation for Development (OECD). Van der Marel and Shepherd (2013) confirm that ICT capital and legal institutionsare particularly important determinants of a country's ability to successfully export services.

Further, the tradability indices are strongly correlated with important factors like country productivity and size, factor endowment, trade costs and regulatory measures.Geishecker and Görg (2008) claim that measuring both service and material offshoring isnot straightforward and is greatly limited in available data on coherent and comparableinformation on such activities. Thus, trade economists usually revert to measuring trade in intermediaries as proxy. In addition, they assessed the impact of off shoring activities in an industry on individual wages which are conceptualized as average hourly gross labourearning including bonus, premium and other extra payments. The explanatory variables are demographic and human capital variables including age, age squared, dummies for the presence of children and being 
married, job tenure, tenure squared, a high education indicator, dummies for occupation and dummies for firm size and regional dummies. Their results show that workers in industries with increasing levels of off shoring services were likely to experience reduction in their wages. They conclude what would have beenconsidered as a perfect case of spillovers from ICT using conventional methods -- the impactof research and development and other intangible capital.

Madeira, Jorge, Sousa, Moreira and Mainardes (2014) investigated the main determinantsof innovation in the service sector in the area of innovation activities. They found the use ofthe logit model to be appropriate for measuring direct and indirect effects of a selected setof explanatory variables of the innovation capacity of Portuguese service firms. They pointout the existence of several factors that stimulate and limit the innovation capacities of firmssuch as investments in innovation activities, firm size and the sub-sector service in the sectorof the activity.

Many research findings show that the contribution of research and development activities inthe growth of the economic sector in any country is fundamental. Jafaridehkord et al., (2015)have argued that firms benefit immensely from spending on their human capital because thisinvestment adds value to their companies. Heshmati and Kim (2012) discuss the fact that adecrease in research and development investment results in decreasing productivity growth. Schoonjans et al., (2013) claim that the effect of knowledge networking on firm growth is significantly larger for service firms than for manufacturing firms since it positively affects net asset and value added growth of service firms.

According to Du and Temouri (2015), firms in both manufacturing and service sectors are likely to become high-growth firms (HGF) when they exhibit higher TFP. The TFP growth model shows that openness to foreign companies and the world economy, restructuring the economy through a shift of resources between sectors and the presence of foreign companies in Malaysia are major contributors to TFP growth (Jajri, 2008).

\section{Methodology}

This study adopted a descriptive survey. Descriptive survey research design is a scientific method which involved observing and describing the behavior of a subject without influencing it in any way (Cooper \& Schindler, 2008). It employed both quantitative and qualitative approaches.

The study used CUSUM test for to examine parameter stability in model. The cumulative sum of recursive residuals (CUSUM) tests are proposed by Brown, Durbin \& Evans (1975). The CUSUM and CUSUMQ are quite general tests of structural change in that they do not require prior determination of where the structural break takes place. Then the model is specified as follow:

This study follows typical Augmented Dickey Fuller unit root technique to verify the stationary of time series data, The unit root model will test with constant, with constant and trend and without constant and trend respectively. The stationary of series test is based on following equation:

$$
\Delta X_{t}=\beta_{0}+\beta_{1} X_{t-1}+\beta_{2} X_{t}+\beta_{3} \Delta X_{t-1}+\ldots \ldots \beta_{p-1} \Delta X_{t-p+1}+I_{t}
$$

Johenson co integration technique for long run relationship analysis, VAR criteria used to follow the lag selection also selected through Akaike\& Schwarz criteria. The long run equation is as follows;

$$
L S E V=\left[\beta_{1} L S E V_{t-1}-\beta_{2} L R_{t-1}-\beta_{3} G R_{t-1}-\beta_{4} L F D I-\beta_{5} L G D P R+\beta_{0}\right]+\varepsilon_{1}
$$

For short run analysis this study follow vector error correction. Since the equation for short run as:

1. $\triangle L S E V=\theta_{0}\left[\beta_{1} L S E V_{t-1}-\beta_{2} G R_{t-1}-\beta_{3} L F D I-\beta_{4} L G D P R+\beta_{0}\right]+\varepsilon_{1}$

2. $\Delta G R=\theta_{1}\left[\phi_{1} L S E V_{t-1}-\phi_{2} L F D I-\phi_{3} L G D P+\phi_{0}\right]+\varepsilon_{1}$

3. $\Delta L R=\theta_{2}\left[\delta_{1} L S E V_{t-1}-\delta_{2} L F D I-\delta_{8} L G D P R+\delta_{0}\right]+\varepsilon_{1}$

4. $\triangle L F D I=\theta_{3}\left[\pi_{1} L S E V_{t-1}-\pi_{2} G R-\pi_{3} L G D P R+\pi_{0}\right]+\varepsilon_{1}$

5. $\triangle L G D P R=\theta_{7}\left[\kappa_{1} L S E V_{t-1}-\kappa_{2} L R_{t-1}-\kappa_{3} L F D I+\kappa_{0}\right]+\varepsilon_{1}$ 
Where the element $\varepsilon_{t}$ are white noise error and $\theta S$ are speed of adjustment and $\vartheta, \eta, \kappa, \psi, \lambda, \zeta, \pi, \delta, \phi$, and $\beta$ are short run parameters.

Where;

\begin{tabular}{ll}
\hline VARIABLES & EXPLANATION \\
\hline FDI & stands for logged foreign direct investment \\
GR & Stands for logged GDP growth rate (GDPR). \\
LR & stands for logged labour participation rate \\
SERV & stands for logged share of services in GDP (SER) as explained variable \\
$\varepsilon$ & stands for logged error term. \\
\hline
\end{tabular}

Share of services in GDP (SER) as explained variable, and explanatory variables such that, population size, external as well as internal factors. It is anticipated total population would positively connect. The control variables are further divided into two sets; external factors and domestic factors. The external factors contain foreign direct investment (FDI). Further second set of control variable comprises labour participation rate (LR) and GDP growth rate (GDPR).

This study requires the combination of several techniques and methods. For the collection of data, secondary data was used. Annual time series data were corrected from national statistic of Rwanda.

\section{Results and Discussion}

At the first step, the Augmented Dickey -Fuller (ADF) (Dickey and Fuller, 1981) unit root test is applied to all the variables to test for the stationarity of these variables. The test is applied to both the original series (in log form) and to the first differences.

Table 1. Unit root test at level

\begin{tabular}{lllllll}
\hline Variable & \multicolumn{2}{l}{ Trend and intercept } & Intercept & \multicolumn{3}{l}{ None } \\
& t-test statistics & Lag Length & t-test statistics & Lag Length & t-test statistics & Lag Length \\
LSERV & -0.682 & 2 & 5.09 & 2 & 9.38 & 2 \\
LFDI & 2.32 & 2 & 5.37 & 2 & 6.44 & 2 \\
LLR & -1.90 & 2 & -0.99 & 2 & 3.12 & 2 \\
LGR & 2.32 & 2 & 5.37 & 2 & 6.44 & 2 \\
\hline
\end{tabular}

Source: Elaborated by the researcher using data from BNR, 2020

$*, * *$ and $* * *$ indicates rejection of the null hypothesis of unit root at $10,5 \%$ and $1 \%$ significant level, respectively.

The SERV, FDI, LR, GR series are not stationary at level, and then researcher should test the Stationarity at the first difference except GE that has stationarity at level on I (2) based on data collected in BNR.

Table 2. Unit root at $1^{\text {st }}$ difference

\begin{tabular}{lllllll}
\hline Variable & \multicolumn{2}{l}{ Trend and intercept } & Intercept & None \\
\hline & t-test statistics & Lag Length & t-test statistics & Lag Length & t-test statistics & Lag Length \\
LSERV & $-\mathbf{5 . 0 2 * * *}$ & 2 & $-2.11^{* * *}$ & 0 & $-0.76^{* * *}$ & 0 \\
$\Delta$ LFDI & $-\mathbf{7 . 1 8 * * *}$ & 2 & $0.08^{* * *}$ & 2 & $0.82 * * *$ & 2 \\
$\Delta$ LLR & $-4.36^{* *}$ & 2 & $-4.43^{* * *}$ & 2 & $-3.13^{* * *}$ & 2 \\
$\Delta$ LGR & $-4.36^{* *}$ & 2 & $-4.43^{* * *}$ & 2 & $-3.13^{* * *}$ & 2 \\
\hline
\end{tabular}

Source: Elaborated by researcher using data from BNR, 2020

$(*),(* *) \&(* * *)$ represent respectively $10 \%, 5 \%$ and $1 \%$ level of significance.

After having differentiated once each one of these series, SERV, FDI, LR, GR become stationary at first difference they are all integrated of order one I(1) means that cointegration of variables is possible . 


\subsection{Selection of Lag Length}

The criteria for selecting the lag length consist of important step. These are different tests that would indicate the optimal number of lags. A critical element in the specification of VAR models is determination of the lag length of the VAR.

Various lag length selection criteria are defined by different authors like, Akaike's (1969) final prediction error (PPE), Akaike Information Criteria (ACI) suggested by Akaike (1974), Schwarz Criterion (SC) (1978) and Hannan-Quinn Information Criterion ( HQ) (1979).

Table 3. VAR Lag Order Selection Criteria

\begin{tabular}{|c|c|c|c|c|c|c|}
\hline \multicolumn{7}{|c|}{ VAR Lag Order Selection Criteria } \\
\hline \multicolumn{7}{|c|}{ Endogenous variables: SERV, FDI, LR, GR } \\
\hline \multicolumn{7}{|c|}{ Exogenous variables: $\mathrm{C}$} \\
\hline \multicolumn{7}{|c|}{ Date: $25 / 10 / 20$ Time: $18: 38$} \\
\hline \multicolumn{7}{|c|}{ Sample: 19952020} \\
\hline \multicolumn{7}{|c|}{ Included observations: 24} \\
\hline Lag & $\log \mathrm{L}$ & LR & FPE & AIC & $\mathrm{SC}$ & HQ \\
\hline 0 & -116.8964 & NA & 0.008127 & 9.376646 & 9.618587 & 9.446316 \\
\hline 1 & 7.352475 & 191.1521* & $4.10 \mathrm{e}-06^{*}$ & 1.742117 & $3.193767 *$ & $2.160140 *$ \\
\hline 2 & 32.42212 & 28.92651 & $5.19 \mathrm{e}-06$ & $1.736760^{*}$ & 4.398118 & 2.503135 \\
\hline
\end{tabular}

* indicates lag order selected by the criterion

Notes: The findings indicate the optimal lag length of $\mathbf{1}$ for the Johansen Co-integration test

\subsection{Cointegration Test}

Themost recently used model for examining long -run equilibrium of gross domestic product, interest rate and money supply is the cointegration technique. Many researchers including the giants in the field of money ( for example, Hafer and Jansen, 1991, Miller,1991 and Friedman and Kuttner,1992) used this technique and found long run equilibrium between nominal gross domestic product and money supply and its explanatory variables. However, this long run relationship may vary from country to country. In the empirical analysis, after knowing whether the series are stationary or not, the cointegration test is the next step.

Before estimating an econometric model one might first -difference the time series, due to the fact that most of macroeconomic series are non- stationary. But according to Hafer and Jansen (1991), this can remove much of the long-run characteristics of the data. However, Engle and Granger (1987) noted that, even though most macroeconomic series are non -stationary, economic theory often provides a rationale why certain variables should obey certain equilibrium constraints. It is the meeting of those equilibrium constraints that serves as a measure of stability: a critical aim of this study.

Table 4. Johansen cointegrating test for (trace test) Unrestricted Cointegration Rank Test (Trace)

\begin{tabular}{lllll}
\hline Hypothesized No. of CE(s) & Eigenvalu & Trace Statistic & 0.05 Critical Value & Prob.** \\
\hline None ${ }^{*}$ & 0.756379 & 87.19183 & 76.97277 & 0.0067 \\
At most 1 & 0.529951 & 50.47611 & 54.07904 & 0.1009 \\
At most 2 & 0.445016 & 30.84821 & 35.19275 & 0.1365 \\
At most 3 & 0.308529 & 15.53901 & 20.26184 & 0.1971 \\
At most 4 & 0.204449 & 5.946726 & 9.164546 & 0.1949 \\
\hline
\end{tabular}

Trace test indicates 1 cointegrating eqn(s) at the 0.05 level

* denotes rejection of the hypothesis at the 0.05 level

**MacKinnon-Haug-Michelis (1999) p-values

These results give an indication for the existence of long-run relationship between SERV and growth. The max and trace values statistic strongly reject the null hypothesis for "none "cointegration vector in favor of at least one cointegrating vectors at the 1 percent significance level. Therefore the cointegrating vector indicated is given follows, 
Table 5. Johansen cointegrating test for (max eigen value) Unrestricted Cointegration Rank Test (Maximum Eigenvalue)

\begin{tabular}{lllll}
\hline Hypothesized & & Max-Eigen & 0.05 & \\
\hline No. of CE(s) & Eigenvalue & Statistic & Critical Value & Prob.** \\
None ${ }^{*}$ & 0.756379 & 36.71572 & 34.80587 & 0.0292 \\
At most 1 & 0.529951 & 19.62790 & 28.58808 & 0.4412 \\
At most 2 & 0.445016 & 15.30920 & 22.29962 & 0.3501 \\
At most 3 & 0.308529 & 9.592288 & 15.89210 & 0.3730 \\
At most 4 & 0.204449 & 5.946726 & 9.164546 & 0.1949 \\
\hline
\end{tabular}

Max-eigenvalue test indicates 1 cointegrating eqn(s) at the 0.05 level

* denotes rejection of the hypothesis at the 0.05 level

**MacKinnon-Haug-Michelis (1999) p-values

Notes: These results give an indication for the existence of long-run relationship between SERV and growth. The max and trace values statistic strongly reject the null hypothesis for "none "cointegration vector in favor of at least one cointegrating vectors at the 1 percent significance level.

\subsection{Long-Run Relationships Among Variables}

The researcher analyzed relationship between service sector and factors of growth in long tine as indicated in the following table from eviews7.

Table 7. Normalized cointegrated coefficients for serv

\begin{tabular}{lllll}
\hline \multicolumn{1}{l}{ 1 Cointegrating Equation(s) } & Log likelihood & 66.48259 & \\
\multicolumn{1}{l}{ Normalized cointegrating coefficients } & (standard & eror in parentheses) & & \\
LISERV & LFDI & LLR & GR & C \\
1.000000 & -0.888601 & -0.032433 & -0.038346 & -2.036392 \\
& $(0.72316)$ & $(0.81217)$ & $(0.40879)$ & $(0.16723)$ \\
\hline
\end{tabular}

Computed by researcher with eviews 7

The cointegrating vector representing the long -run relationship between inflation its determinants

\section{LSERV=2.03+0.88LFDI+0.0LLR+0.03LGR}

In this equation, all the estimated of the coefficients of the variables have the correct sign and are statistically significant to explain the dependent variable.

The cointegrating vector representing the long-run relationship between inflation and its determinants. In this equation, all the estimates of the coefficients of the variables have the correct sign and are statistically significant. The results show that, if ceteris paribus $1 \%$ increases on FDI increases SERV by $0.88 \%$, if ceteris paribus $1 \%$ increases on LR affect SERV by $0.03 \%$. The first hypothesis stated thatthere is a strong relationship between service sector and Rwanda economic growth have been confirmed.

This finding is in conformity with Nachega (2001) who argued that in developing countries where interest rate ceiling and capital controls prevail, assets substitution is likely to be between money and physical assets rather than between money and financial assets. This means that physical assets are substitutes of money in Rwanda and thus, inflation leads to a shift from money holding to asset holding. Suggesting that demand for money also has implications for portfolio decisions in Rwanda. The coefficient of SERV rate (2.741) shows that the currency-substitution phenomenon does not hold in Rwanda. The positive estimated coefficient on exchange rate is consistent with the fact that depreciation of domestic currency raises the domestic currency value of an individual's foreign assets, and if this is perceived as an increase in wealth, then money demand would increase (Arango and Nadiri, 1981). This means that the wealth-effect of currency depreciation dominates the currency substitution-effect of currency depreciation in Rwanda in the long-run which postulates that unemployment increases in Rwanda when there is depreciation. The wealth-effect could be attributed to the fact that remittances play a very crucial role in the Rwandan economy. Depreciation may be perceived as an increase in wealth because it raises the domestic value of dollar inflows which would increase money supply in the Rwanda. An Adjusted R-squared of 0.993, used to measure the goodness-of-fit of the estimated model, indicates that the model explain about 99 per cent of the long-run behavior of inflation in Rwanda.

\subsection{Dynamic Error Correction Model}

After the determination of the cointegrating relationship, the next step is to estimate the short-run demand for service sector using Vector autocorrelation. The short-run model coefficients measure the dynamics of the model, the Vector autocorrelation measures the speed of adjustment to the long run equilibrium which is taking place. 
Table 8. short-run model for INF and its determinates

Vector Error Correction Estimates

Date: 25/10/19 Time: 08:56

Sample (adjusted): 19952020

Included observations: 24 after adjustments

Standard errors in ( ) \& t-statistics in [ ]

Cointegration Restrictions:

$\mathrm{A}(2,1)=0$

Convergence achieved after 88 iterations.

Not all cointegrating vectors are identified

LR test for binding restrictions ( $\operatorname{rank}=1)$ :

Chi-square(1)

17.77348

Probability

0.000025

Cointegrating Eq:

CointEq1

LFDI $(-1)$

$-0.306407$

$\operatorname{LLR}(-1)$

$-1.759285$

$\operatorname{LGR}(-1)$

0.256094

$\operatorname{ISERV}(-1)$

0.134112

$\mathrm{C}$

7.521730

Source: Eviews7 (2020)

The above is endogenous because its probability of chi-square 0.000025 is less than $5 \%$ level of significance and it answers the second hypothesis of a Variable that can help national bank of Rwanda to control service sector in the short-run. Note that only foreign direct investment is adjustment variable of Service model, commercial bank deposit, and commercial bank lending rate are endogenous for servise model meaning that they can be used only for long-run

\subsection{Wald Test for Significance of Parameters}

Researchers analysedWald test for significance of parameters during the period of study.

Table 9. Wald test

\begin{tabular}{llll}
\hline Wald Test: & & & \\
\hline Equation: Untitled & & Df & Probability \\
Test Statistic & Value & $(10,14)$ & 0.1142 \\
F-statistic & 2.002093 & 10 & 0.0791 \\
Chi-square & 20.02093 & &
\end{tabular}

Source: Eviews7 (2020)

From the above test due to the P- value of chi-square which is $\mathbf{0 . 0 7 9 1}$ and this is greater than 0,05 level of significant therefore, there is no short run causality between variables running from SERV, FDI, LR, and GR to at 5\% level of significant. This means that there is long run causality between variables running from SERV, FDI, LR and GR to at $5 \%$ level of significant.

\subsection{Granger Causality Test Between Service and Growth}

If a relationship between two variables $\mathrm{X}$ and $\mathrm{Y}$ exists, whether positive or negative, it is not necessary to denote that $\mathrm{X}$ is causing $\mathrm{Y}$, or $\mathrm{Y}$ is causing $\mathrm{X}$, or $\mathrm{X}$ and $\mathrm{Y}$ are causing one another. However, if $\mathrm{X}$ is causing $\mathrm{Y}$, then $\mathrm{X}$ contains some useful information about $\mathrm{Y}$ that enables us to predict the value of $\mathrm{Y}$ efficiently.

The idea behind the Causality technique (Granger, 1969) is not to find the relationship between the variables, but to test the causality between them. For example, if SERV (X) is positively related to the (SERV, FDI, LR, and GR), then we use the Granger causality test to figure out the direction of the causality between them. This test determines whether the causality runs from $X$ to infl (FDI, LR AND GR $\rightarrow$ SERV), the causality runs from infl to X (serv $\rightarrow$ FDI, LR AND GR), $\mathrm{X}$ and infl are causing each other (FDI, LR AND GR $\leftrightarrow$ infl), or the causality between $\mathrm{X}$ and serv does not exist. Therefore, in order to verify the relationship among variables proxies under this study we use Granger causality test and the results are shown in the following table. 
Table 10. Granger Causality Tests

Pairwise Granger Causality Tests

Date: 15/11/19 Time: 09:51

Sample: 19952018

Lags: 2

Null Hypothesis:

L FDI, LR AND GR does not Granger Cause SERV

Obs F-Statistic Prob.

LSERV does not Granger Cause L FDI, LR AND GR

$\begin{array}{lll}27 & 2.72940 & 0.0284\end{array}$

Source: Eviews7 (2020)

$2.32569 \quad 0.1224$

Referring to the results revealed out from the above table; L FDI, LR AND GR does Granger Cause LSERV at $10 \%$ level of significant due to their probability of 0.0284 which is less than 0.10 level of significance but SERV does not Granger Cause FDI, LR AND GR at 10\% level of significant due to their probability of 0.1224 which is greater than 0.10 level of significance. To these results there is unidirectional causality running from FDI, LR AND GR to SERV at $10 \%$ level of significance.

\subsection{Diagnostic Test of Residuals}

The diagnostic test was also used to find out if the service sector is stable in Rwanda during the period under study (1990 t0 2018). The Residual Histogram Normality test of Jarque-Bera and Serial Correlation test of Breusch-Godfrey was conducted.

\subsubsection{Normality Test}

With the assumption of normality, the test of Jarque- Bera will show us if the residual at a given period of time are not only correlated but also distributed normally. The test for normality of residuals plays a crucial role, because it precise the statistic distribution of estimators.

It's due to this hypothesis that inference statistic could be realized. The results of this test are shown at the graph below:

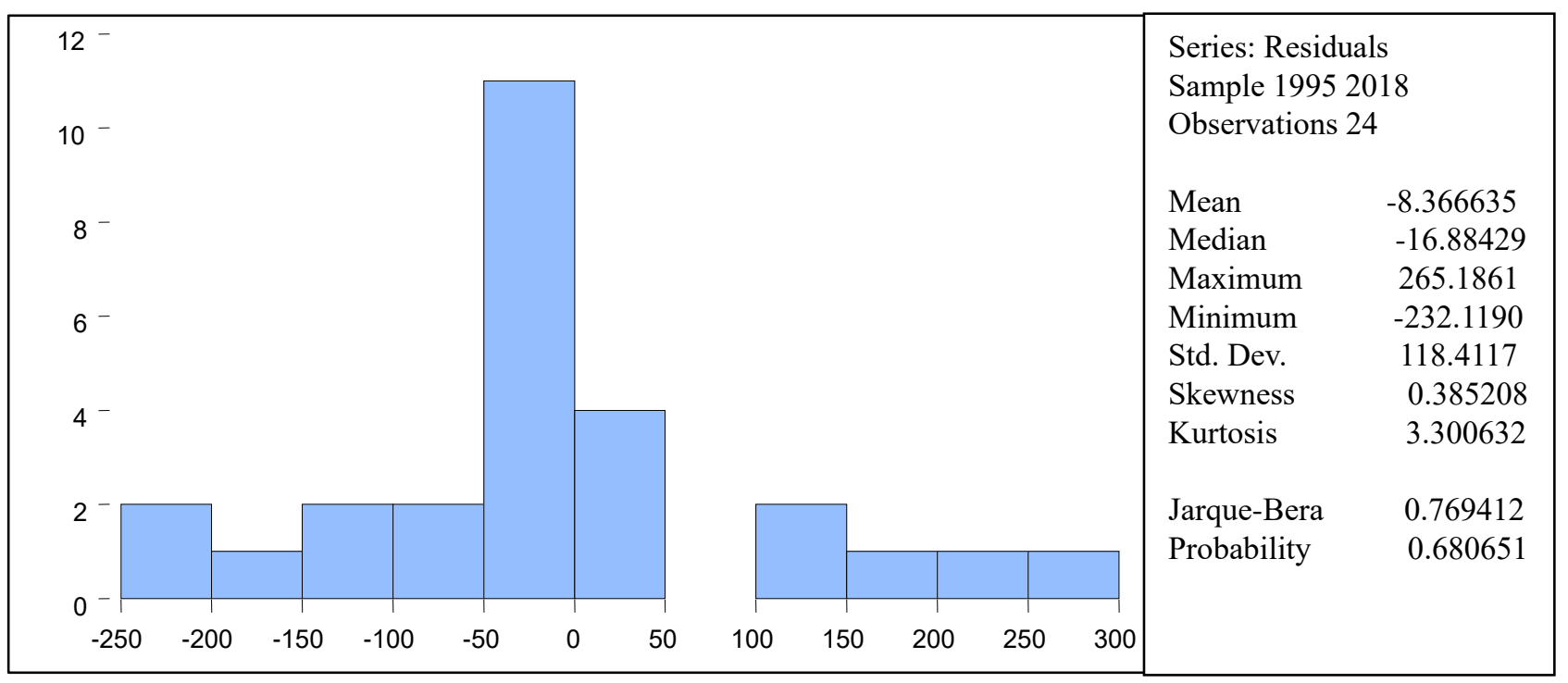

Figure 2. Histogram Normality test

Source: Eviews7 (2020)

As probability of Jarque-Bera equals 0.680651 or $68.06 \%$ respectively which is greater than $10 \%$ reference of significance level, the residuals in our model are normally distributed, and this reflects the good quality of our model.

\subsubsection{Serial Correlation Test}

To test if there is a serial Correlation of residuals the researcher used Breusch-Godfrey test. This test shows whether the model contains problems of autocorrelations of residuals. It means that errors of the period $(t)$ affect the errors of the $\operatorname{next} \operatorname{period}(t+1)$.

The following hypotheses were tested:

Ho: Residuals are not serially correlated 
H1: Residuals are serially correlated

We reject the null hypothesis if the Chi-square value after running Breusch-Godfrey test is less than $5 \%$ then there is a serial correlation of residuals in the model.

Table 11. Serial correlation test

\begin{tabular}{lrll}
\hline Breusch-Godfrey Serial Correlation LM Test: & & \\
F-statistic & 7.755412 & Prob. F(2,18) & 0.0037 \\
Obs*R-squared & 11.13398 & Prob. Chi-Square(2) & 0.0038 \\
\hline
\end{tabular}

Source: Eviews7 (2020)

In the table above the chi-square is equals to 0.0038 which is less that $10 \%$, thus in our model there is a serial correlation of residuals, it means that the model contain the problem of residuals autocorrelation.

5.8 Heteroskedasticity Test

To test if the errors are constant or not the researcher conducted the heteroskedasticity test by using the Breusch-Pagan-Godfrey test and the following hypothesis well tested:

Ho: There is no heteroskedasticity of residuals

Ha: There is heteroskedasticity of residuals

We reject null hypothesis if the Chi-square value after running Breusch-Godfrey test is less than $5 \%$.

Table 12. Heteroskedasticity Test

\begin{tabular}{llll}
\hline Heteroskedasticity Test: Breusch-Pagan-Godfrey & & \\
F-statistic & 1.678626 & Prob. F(6,20) & 0.1781 \\
Obs*R-squared & 9.042950 & Prob. Chi-Square(6) & 0.1712 \\
Scaled explained SS & 5.983778 & Prob. Chi-Square(6) & 0.4250 \\
\hline
\end{tabular}

Source: Eviews7 (2020)

The Chi-square probability is greater than $5 \%$; we do not reject the null hypothesis, it means that the errors of homoscedasticity are accepted, there is no heteroskedasticity of residuals, it means that errors are constant. The observed estimations by OLS are optimal.

\subsection{Stability Diagnostic}

\subsubsection{Ramsey Reset Test}

The Ramsey reset was employed to determine if the model has omitted a relevant variable and it indicates whether the model is correctly specified.

Table 13. Ramsey reset test

\begin{tabular}{llll}
\hline Ramsey RESET Test & & & \\
Equation: SREQ01 & & & \\
Specification: (D(SERV) D(FDI) D(LR) D(GR)) & & & \\
Omitted Variables: Squares of fitted values & Value & 19 & Probability \\
& 5.386839 & $(1,19)$ & 0.0000 \\
t-statistic & 29.01804 & 1 & 0.0000 \\
F-statistic & 24.10558 & 1 & \\
Likelihood ratio &
\end{tabular}

Source: Eviews7 (2020)

The test shows that because the probability is 0.0000 is less than $5 \%$, there is a good specification of the model, and then the model is correctly specified and stable.

\subsubsection{Durbin Watson (DW) Test}

This test serve to check if the model is spurious or not. The hypotheses to analyze this test are:

Ho: The model is spurious

H1: The model is not spurious

We reject the null hypothesis if the value of DW is greater than the R-square value $\left(D W>R^{2}\right)$ 
We have the Durbin Watson equal to 1.032 which is greater than the R-squared 0.126 , so we reject the null hypothesis, which mean that the model is not spurious.

\subsubsection{Recursive Test (CUSUM)}

The CUSUM test is based on the cumulative recursive sum of recursive residuals. The CUSUMSQ test, on the other hand, is based on the cumulative sum of squares of recursive residuals. Both the CUSUM and CUSUMSQ test statistics are updated recursively and plotted against break points in the data. For stability of the short-run dynamics and the long-run parameters of gross domestic product function, it is important that the CUSUM statistics stay within the 5\% critical bound (represented by two straight lines whose equations are detailed in Brown et al., 1975 aforementioned). This cumulative sum test shows graphical navigation of variables of the method within a perspective of judging the stability of parameters. When the blue curve goes out of the corridor of red lines (which indicates the critical bounds at $5 \%$ level of significance) the coefficients of the model are not stable; otherwise, the coefficients of the model are stable.

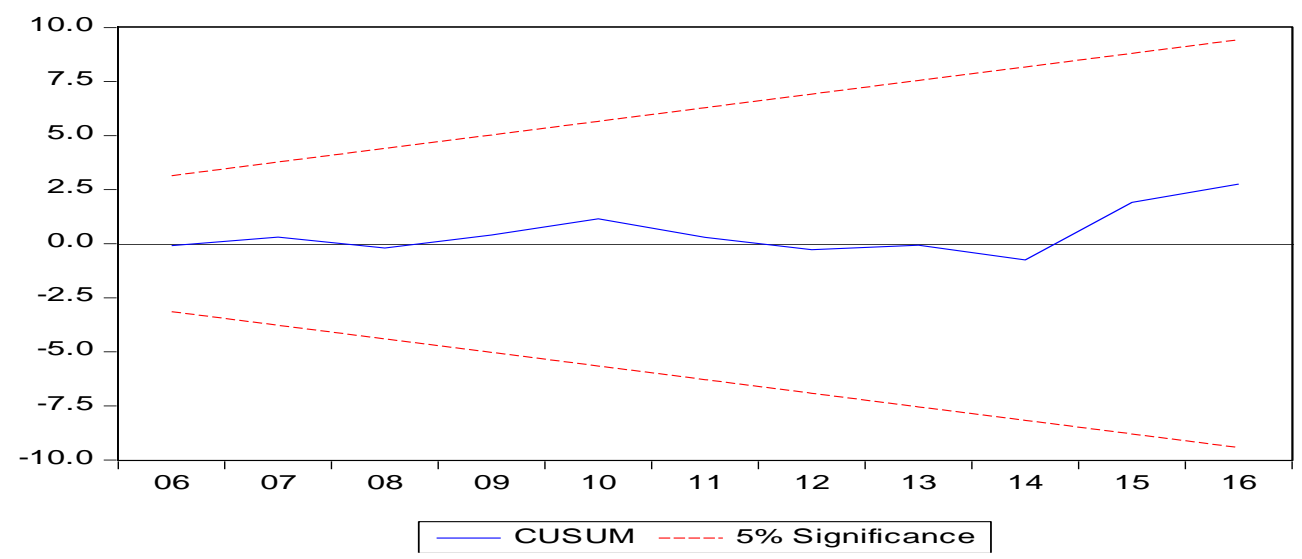

Figure 3. Cusum Test

Source: Eviews7 (2020)

In the current research the coefficients of the model are stable, because the navigating blue line of CUSUM graph does not cross the red critical borders. This indicates that, basing on service sector, foreign direct investment, labor participation and GDP growth rate in Rwanda have been moving in an a fluctuating model but with stable economic way during the period of twenty eight years from 1995 up to 2020.

\subsection{Interpretations and Discussion of the Results}

The results shows that the inflation is stationary at their levels, and their first differences, means that they are integrated of order zero $\mathrm{I}(\mathrm{O})$ and order one $\mathrm{I}(1)$, while service sector, foreign direct investment, labor participation and GDP growth rateare not stationary at level, but stationary on their first difference with lag 2 . The results of cointegration in Table of trace and Eigen value statistics revealed that there are 5 and 3 cointegrations between dependents and independents variables.

The results of VECM revealed that the SERV is in long run and in short run relationship with, foreign direct investment, labor participation and GDP growth rate, which contradict the hypothesis two of this study. The results in was confirmed our first objective that states that there is relationship between service sector and foreign direct investment, labor participation and GDP growth rate. The results of this research do not contract with past studies as the empirical reviewed.

\section{Conclusion}

This study aims to examine if service sector is an engine of growth in Rwanda (1995-2020). Multiple linear regressions model was applied on time series data for the period of 1995-2020. The results from the study illustrate that service sector; foreign direct investment, labor participation and GDP growth rate are strong drivers of growth in Rwanda. Whereas significantly government expenditures has positive effects on service sector. Therefore, findings also proved that a foreign direct investment impact on service sector is insignificant but positive; and government spending insignificantly affects service sector positively. Along with the findings of estimated regression, the outcomes of this study could be used by policy makers in Rwanda to frame a suitable economy policy. Moreover, the study found that growth is mainly accelerated by the service sector side (high cost of inputs productions) and external factors (FDI). 
It is suggested to:

$>$ Put in place services innovation policy complementing existing employment with emphasis on the employees' development and enhanced training strategies;

$>$ Develop gender sensitive employment policy to ensure full participation of women in economic sector especially in the service sector;

$>$ Facilitate private sector operators in purchasing fixed asset like by tax exemption or subsidizing some strategic assets for service sector expansion;

$>$ Expand ICT application to becoming service mobile based by targeting countryside population;

$>$ Regulate the monetary policy in the way that financial institutions can provide loan to service sector's operators; and

$>$ Putting in place the foreign trade policy with emphasis to service export in its all forms to benefit from existing economic integration.

\section{References}

Chude, D., Izuchukuru, \& Nkuru, P. (2015). Impact of company income taxation on the profitability of companies in nigeria: a study of nigerian breweries. European Journal of Accounting, Auditing and Finance Research, 3(8), $1-11$.

Das, L., \& Raut, R. (2014). Impact of Changes in Service Sector in India in Shaping the Future of Business and Society. Procedia Economics and Finance, 11, 795-803. https://doi.org/10.1016/S2212-5671(14)00243-3

Drejera, I. (2002). Business Services as a Production Factor. Economic Systems Research, 14(4), 389-405. https://doi.org/10.1080/0953531022000024851

Du, J., \& Temouri, Y. (2015). High-growth firms and productivity: evidence from the United Kingdom. Small Business Economics, 44(1), 123-143. https://doi.org/10.1007/s11187-014-9584-2

Eichengreen, B., \& Gupta, P. (2011). The Service Sector as India's Road to EconomicGrowth. NBER Working Paper No. 1675. https://doi.org/10.3386/w16757

El-Said, O. A., \& Kattara, H. S. (2013). Customers'preferences for new technology-basedself-services versus human interaction services in hotels. Tourism and HospitalityResearch, 13(2), 67-82. https://doi.org/10.1177/1467358413519261

Fuchs, V. R. (1980). Economic Growth and the Rise of Service Employment. NBER WorkingPaper, No. 486. https://doi.org/10.3386/w0486

Jajri, I. (2008). Determinants of total factor productivity growth in Malaysia. Journal ofEconomic Cooperation, 28(3), 41-58.

Johnsen, G. J., \& McMahon, R. G. P. (2005). Owner-manager Gender, Financial Performanceand Business Growth amongst SMEs from Australia's Business Longitudinal Survey. International Small Business Journal, 23(2), 115-142. https://doi.org/10.1177/0266242605050509

Kay, D. L., Pratt, J. E., \& Warner, M. E. (2007). Role of service in regional economic growth. Growth and Change, 38(2), 419-442. https://doi.org/10.1111/j.1468-2257.2007.00377.x

Khan, K. S. (2011). Determinants of Firm Growth: An Empirical Examination of SMEs inGujranwala, Gujarat and Sialkot Districts. Interdisciplinary Journal of ContemporaryResearch in Business, 3(1), 1389-1409.

King, R. G., \& Levine, R. (1993). Finance and Growth: Schumpeter might be right. The Quarterly Journal of Economics, 108(3), 717-737. https://doi.org/10.2307/2118406

Latha, C. M., \& Shanmugam, V. (2014). Growth of Service Sector in India. Journal of Humanities and Social Science, 19(1), 08-12. https://doi.org/10.9790/0837-19140812

Lenaerts, K., \& Merlevede, B. (2015). Firm size and spillover effects from foreign directinvestment: the case of Romania. Small Business Economics, 45(3), 595-611. https://doi.org/10.1007/s11187-015-9652-2

Liu, L., \& Nath, H. K. (2013). Information and Communications Technology and Trade inEmerging Market Economies. Emerging Markets Finance and Trade, 49(6), 67-87. https://doi.org/10.2753/REE1540-496X490605

Mihalic, T., Praniceric, D. G., \& Arneric, J. (2015). The changing role of ICTcompetitiveness: the case of the Slovenian $\begin{array}{llll}\text { hotel sector. } & \text { Economic Research-EkonomskaIstraživanja, } & \text { 28(1), }\end{array}$ https://doi.org/10.1080/1331677X.2015.1043779 
Mujahid, H., \& Alam, S. (2014). Service Sector as an Engine of Growth. Asian Economicand Financial Review, 4(3), 377-386.

Muro, M. B., Magutu, P. O., \& Getembe, K. N. (2013). The strategic benefits and challengesin the use of customer relationship management systems among commercial banks inKenya. European Scientific Journal, 9(13), 327-349.

Nassazi, A. (2013). Effect of training on employee performance with evidence from Uganda. Business Economics and Tourism, 1-57.

NISR. (2014). Establishment census. Kigali: National Institute of Statistics of Rwanda.

Oliveira, B., \& Fortunato, A. (2008). The Dynamics of the Growth of Firms: Evidence fromthe Services Sector. Empirica, 35(3), 293-312. https://doi.org/10.1007/s10663-008-9065-4

Olofin, O. P., Olufolahan, T. J., \& Jooda, T. D. (2015). Food Security, Income Growth andGovernment effectiveness in WEST African Countries. European Scientific Journal, 11(31), 417-429.

Powers, A. D., \& Xie, Y. (1999). Statistical Methods for Categorical Data analysis. Austin: Academic Press, Inc. https://doi.org/10.1016/B978-012563736-7/50005-7

Prajogo, D. I., \& Sohal, A. S. (2006). The integration of TQM and technology/R\&Dmanagement in determining quality and innovation performance. Omega, 34(3), 296-312. https://doi.org/10.1016/j.omega.2004.11.004

Queiro, F. (2016). The efffect of managers education on firm growth. The Quarterly Journalof Economics, 118(4), 1169-1208.

Ramakrishna, G. (2010). Open Policies and Service Sector Growth in India: Does ServiceSector Growth Influence Economic Growth of India? https://doi.org/10.2139/ssrn.1633238

Reuber, A. R., \& Fischer, E. (2002). Foreign Sales and Small Firm Growth: The ModeratingRole of the Management Team. Entrepreneurship Theory and Practice, 27(1), 29-45. https://doi.org/10.1111/1540-8520.271002

Stock, J. H., \& Watson, M. W. (2011). Introduction to Econometrics. (3rd, Ed.) Boston:Pearson Education Inc.

Stoilova, D., \& Patonov, N. (2013). An empirical evidence for the impact of Taxation oneconomy growth in the European Union. Proceedings TMS Int. Conference 2012: Financial Management, Accounting and Taxation, 2, 1031-1039.

Tahir, M., \& Azid, T. (2015). The relationship between international trade openness andeconomic growth in the developing economies: Some new dimensions. Journal of Chinese Economic and Foreign Trade Studies, 8(2), 123-139. https://doi.org/10.1108/JCEFTS-02-2015-0004

UN. (2008). International Standards Industrial Classification of All economic Activities. Revision 4.

UNECA. (2015). Economic Report on Africa 2015:Industrializing through trade.

van der Marel, E., \& Shepherd, B. (2013). International Tradability Indices for Services: Policy Research Working Paper No. 6712. https://doi.org/10.1596/1813-9450-6712

Verbeek, M. (2004). A guide to Modern economitrics (2nd ed.). Rotterdam: John willey \&Sons, LTD.

Watson, J. (2003). Sme Performance: Does Gender Matter. A paper for the Small EnterpriseAssociation of Australia and New Zealand 16th Annual Conference,Ballarat.

WB. (2011). Enterprise surveys: Rwanda country profile 2011. Enterprise surveys countryprofile. Washington, DC: World Bank Group.

Yeboah, O., Naanwaab, C., Saleem, S., \& Akuffo, A. (2012). Effects of Trade Openness onEconomic Growth: The. Birmingham: Agribusiness, Applied Economics andAgriscience Education- NC A\&T. https://doi.org/10.1155/2012/942748

Yli-Renko, H., Autio, E., \& Sapienza, H. J. (2001). Social capital, knowledge acquisition, and knowledge exploitation in young technology-based firms. Strategic Management Journal, 22(6-7), 587-613. https://doi.org/10.1002/smj.183

Zhou, Z. (2015). The Development of Service Economy: A General Trend of the ChangingEconomy. Shanghai: Development research center of shanghai.

\section{Copyrights}

Copyright for this article is retained by the author(s), with first publication rights granted to the journal.

This is an open-access article distributed under the terms and conditions of the Creative Commons Attribution license which permits unrestricted use, distribution, and reproduction in any medium, provided the original work is properly cited. 